\title{
Solierella turneri Dutt, 1917 (Hymenoptera: Crabronidae: Crabroninae) from India: description of female and new distribution records
}

\author{
N.V. Ayisha Mawadda \\ Western Ghat Regional Centre, Zoological Survey of India, Eranhipalam, Kozhikode, Kerala- 673006, India. \\ هayishakmr@gmail.com; (iD https://orcid.org/0000-0003-4649-9428
}

\section{Puthuvayi Girish Kumar}

Western Ghat Regional Centre, Zoological Survey of India, Eranhipalam, Kozhikode, Kerala- 673006, India. هkpgiris@gmail.com; (DiD htps://orcid.org/0000-0003-2121-0165

\author{
Received: \\ 16 June, 2021 \\ ABSTRACT. The crabronid wasp, Solierella turneri Dutt, 1917 (Hymenoptera: Crabronidae) \\ Accepted: \\ 10 December, 2021 \\ is newly recorded from various regions of India and female is described. Hitherto, the \\ S. turneri Dutt has been only reported from northern India (Pusa of Bihar), the current record \\ extends its range to southern India (Kerala, Tamil Nadu and Karnataka). \\ Published: \\ 05 January, 2022 \\ Subject Editor: \\ Christian Schmid-Egger \\ Key words: Digger wasp, Miscophini, Apoidea, new record, Southern India \\ Citation: Mawadda, N.V.A. \& Girish Kumar, P. (2022) Solierella turneri Dutt, 1917 (Hymenoptera: Crabronidae: Crabroninae) \\ from India: description of female and new distribution records. Journal of Insect Biodiversity and Systematics, 8 (1), 111-120.
}

\section{INTRODUCTION}

Species of the genus Solierella Spinola, 1851 (Hymenoptera: Crabronidae) are small to medium sized black wasps with white markings on thorax and legs. The gaster and hind legs are often black with white or creamy white maculae. They nest in pre-existing cavities in stems, twigs, galls or in abandoned burrows in soil. Hemipterans, orthopterans and psocopterans are used for provisioning the nest. Nests are made up of loosely packed cells and are closed by pebbles and pieces of grass (Williams, 1927, 1950; Newton, 1960; de Beaumont, 1964; Krombein, 1967; Kurczewski, 1967; Carrillo \& Caltagirone, 1970; Bitch et al., 2021). The genus Solierella consist of 118 species, worldwide (Pulawski, 2021). Dutt (in R. Turner, 1917) studied this genus from India and erected a species named S. turneri Dutt, 1917 based on a single specimen. Till then, no study about Solierella have been reported from India. The original short description is rather was based on male specimen. So, we described the female here for the first time based on the newly collected specimens from Kerala, Tamil Nadu and Karnataka.

\section{MATERIAL AND METHODS}

This study is based on the specimens collected from the various localities of southern India. Specimens belonging to the genus Solierella were collected using about 20-50 yellow pan traps from different months of the year 2015 to 2020, in different parts of three Southern states of India, i.e., Karnataka, Kerala and Tamil Nadu. Yellow pan traps are placed in different habitats like forest, open land, homestead vegetation etc. About 200-300 specimens were collected and sorted. The specimens are studied using a

Corresponding author: Mawadda, N.V.A., E-mail: ayishakmr@gmail.com

Copyright (C) 2022, Mawadda \& Girish Kumar. This is an open access article distributed under the terms of the Creative Commons NonCommercial Attribution License (CC BY NC 4.0), which permits Share - copy and redistribute the material in any medium or format, and Adapt - remix, transform, and build upon the material, under the Attribution-NonCommercial terms. 
LEICA ${ }^{\circledR}$ M 205A Stereo microscope model and photographed with LEICA ${ }^{\circledR}$ DFC 500 Camera. Photographs of the type, Solierella turneri Dutt (NHMUK012859085, a male), made available from NHMUK under Creative Commons License 4.0 for comparing with collected specimens. The identified specimens are deposited at Western Ghat Regional Centre, Zoological Survey of India, Kozhikode (ZSIK).

The morphological terminology used in this paper follows Bohart \& Menke (1976). The following terms and abbreviations used in the text are redefined as follows: F1: First flagellar segment; G1, G2, G3: First gastral segment, Second gastral segment, Third gastral segment, etc.; HL: Head length; HW: Head width; IODc: Minimum inter ocular distance at base of clypeus; IODv: Minimum inter ocular distance at vertex; OOD: Ocello ocular distance, minimum distance between the posterior ocellus and eye; POD: Posterior ocellar distance, minimum distance between the posterior ocelli. Episcrobal area: Portion of the mesopleuron above the scrobal grove and below the subalar fossa. Maculae: whitish or creamy white spots or marks. The following abbreviations are used for the depositories in the text: NHM: The Natural History Museum, formerly British Museum (Natural History), London, Great Britain; ZSIK: Western Ghat Regional Centre, Zoological Survey of India, Kozhikode, India. The following abbreviations are used for name of collectors: N.V.A.M.: N.V. Ayisha Mawadda; C.B.: C. Binoy; C.C.: C. Charesh; K.A.: K. Anju; K.J.: Kuriakose Junior; K.P.H.R.: K.P. Hanima Raveendran; P.G.K.: P. Girish Kumar; P.M.R.: P.M. Rajan; R.F.: Raseena Farsana; S.A.: S. Anagha; S.S.: Souvik Sen; T.R.: Tessy Rajan; U.M.S.: U.M. Sheeja.

\section{RESULTS}

Taxonomic part

Order Hymenoptera Linnaeus, 1758

Superfamily Apoidea Latreille, 1802

Family Crabronidae Latreille, 1802

Subfamily Crabroninae Latreille, 1802

Genus Solierella Spinola, 1851

Solierella turneri Dutt, 1917 (Figs 1-19)

Solierella turneri Dutt in R. Turner, 1917:205, Holotype, male (gender was not indicated originaly, India: Bihar, Pusa (NHM).

Material examined: INDIA: Karnataka, Kodagu district, Bettathur $\left(12^{\circ} 24^{\prime} 26^{\prime \prime} \mathrm{N}, 7^{\circ} 39^{\prime} 41^{\prime \prime} \mathrm{E} 1063 \mathrm{~m}\right.$ a.s.1.), 10ิ, 23.xii.2019, P.G.K., leg. (ZSIK Regd. No. ZSI/WGRC/IR/INV/15769). Kerala, Malappuram

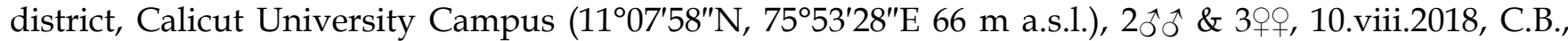

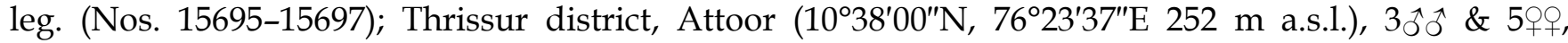
14.iv.2020, N.V.A.M., leg. (Nos. 15703-15710); Kozhikode district, Pazhassi raja Museum (11'17'45"N,

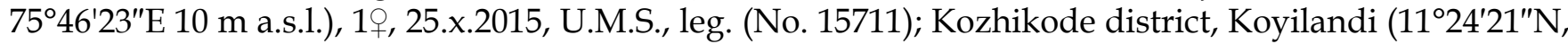

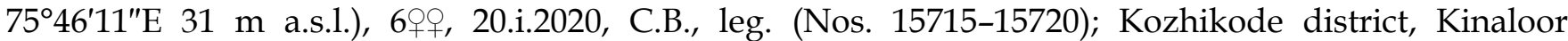
$\left(11^{\circ} 28^{\prime} 04^{\prime \prime} \mathrm{N}, 7^{\circ} 51^{\prime} 39^{\prime \prime} \mathrm{E} 27 \mathrm{~m}\right.$ a.s.l.), 2우, 27.iii.2019, C.B., leg. (Nos. 15742 \& 15743); Kozhikode district,

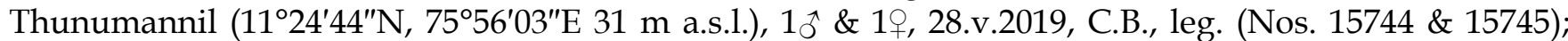

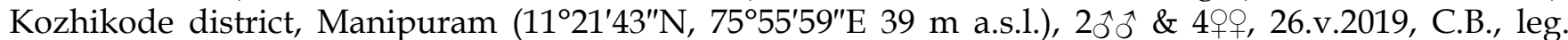

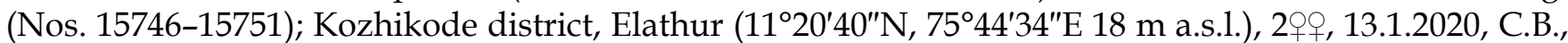

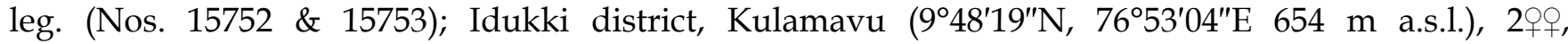

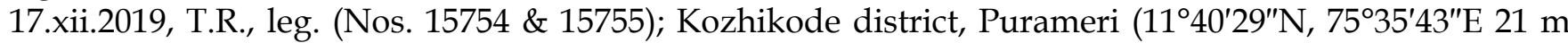

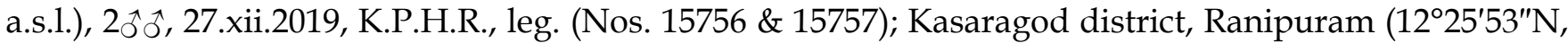
75²1'01"E $1001 \mathrm{~m}$ a.s.1.), 10ิ \& 1, 17.xii.2017, P.M.R., leg. (Nos. 15758 \&15759); Wayanad district, No specific locality, 10ิ, 17.ii.2016, R.F., leg. (No. 15760); Kozhikode district, Jaferkhan colony, Zoological Survey of India campus $\left(11^{\circ} 16^{\prime} 02^{\prime \prime} \mathrm{N}, 7^{\circ} 47^{\prime} 21^{\prime \prime} \mathrm{E} 21 \mathrm{~m}\right.$ a.s.l.), $1 \jmath^{\uparrow} \& 1$ 1, 15.v.2019, K.P.H.R., leg. (Nos.

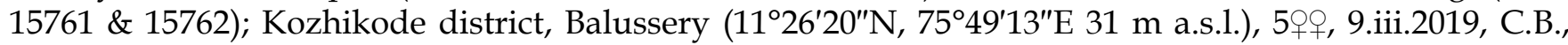


leg. (Nos. 15763-15767); Kozhikode district, Nanminda $\left(11^{\circ} 25^{\prime} 18^{\prime \prime} \mathrm{N}, 75^{\circ} 49^{\prime} 15^{\prime \prime} \mathrm{E} 41 \mathrm{~m}\right.$ a.s.1.), 1우,

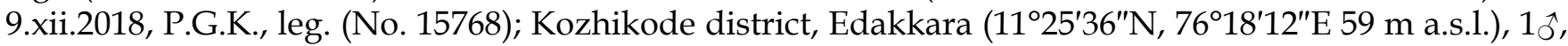

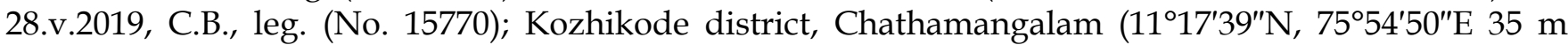

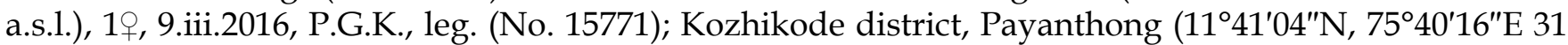
m a.s.1.), 1ㅇ, 30.iii.2019, K.P.H.R., leg. (No. 15772); Thiruvananthapuram district, Kerala Agricultural University Campus, Vellayani $\left(8^{\circ} 26^{\prime} 38^{\prime \prime} \mathrm{N}, 7^{\circ} 59^{\prime} 29^{\prime \prime} \mathrm{E} 2 \mathrm{~m}\right.$ a.s.1.), 2o+ , 1.v.2019, C.B., leg. (Nos. 15773 \& 15774); Kozhikode district, Chemenchery $\left(11^{\circ} 24^{\prime} 58^{\prime \prime} \mathrm{N}, 7^{\circ} 44^{\prime} 07^{\prime \prime} \mathrm{E} 18 \mathrm{~m}\right.$ a.s.1.), 19, 8.xi.2018, C.B., leg.

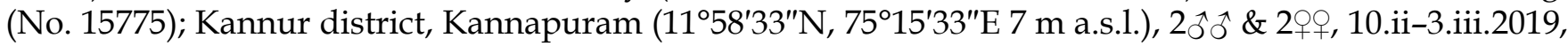
28.iv.2019, C.C., leg. (Nos. 15776-15779); Wayanad district, Kalloor (11 ${ }^{\circ} 40^{\prime} 13^{\prime \prime} \mathrm{N}, 76^{\circ} 18^{\prime} 42^{\prime \prime} \mathrm{E} 851 \mathrm{~m}$ a.s.l.),

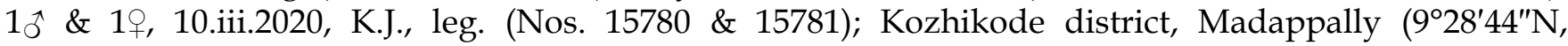
76033'51"E $25 \mathrm{~m}$ a.s.1.), 6수 \& 8우, 16.iii.2020, S.A., leg. (Nos. 15782-15795); Kozhikode district, Pathirippatta $\left(11^{\circ} 41^{\prime} 37^{\prime \prime} \mathrm{N}, 7^{\circ} 42^{\prime 2} 21^{\prime \prime} \mathrm{E} 41 \mathrm{~m}\right.$ a.s.l.), 2우, 14.iv.2020, K.A., leg. (Nos. 15796 \& 15797);

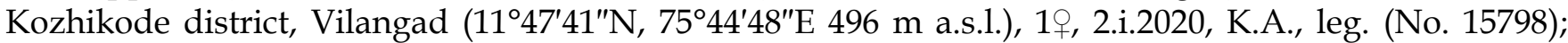
Kannur district, Vilakkottur $\left(11^{\circ} 45^{\prime} 30^{\prime \prime} \mathrm{N}, 7^{\circ} 39^{\prime} 50^{\prime \prime} \mathrm{E} 24 \mathrm{~m}\right.$ a.s.l.), 19, 19.xii.2020, K.P.H.R., leg. (No. 15799). Tamil Nadu, Kanyakumari district, Kanyakumari Wildlife Sanctuary, Alagiyapandipuram range, Keeriparai $\left(8^{\circ} 26^{\prime} 30^{\prime \prime} \mathrm{N}, 7^{\circ} 25^{\prime} 21^{\prime \prime} \mathrm{N} 30 \mathrm{~m}\right.$ a.s.l.), 20ㅊㅎ \& 3우, 14-16.ii.2020, S.S. \& Party, leg. (Nos.

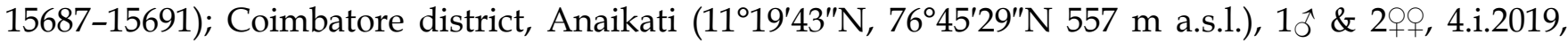

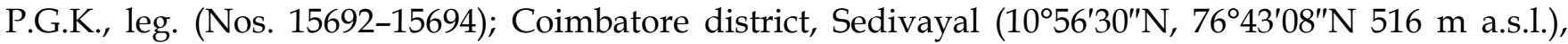

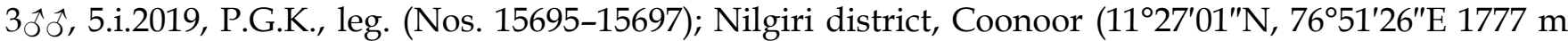
a.s.l.), 1今̂, 7.i.2019, P.G.K., leg. (No. 15712); Kanyakumari district, Kanyakumari Wildlife Sanctuary, Kulashekaram Range, Peechiparai $\left(8^{\circ} 27^{\prime} 31^{\prime \prime} \mathrm{N}, 7^{\circ} 19^{\prime} 01^{\prime \prime} \mathrm{E} 84 \mathrm{~m}\right.$ a.s.1.), 1ㅅ, 20.ii.2020, S.S. \& Party, leg. (No.

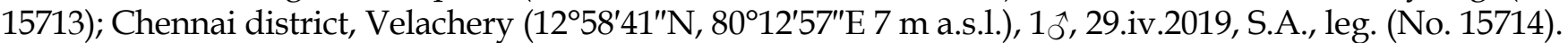

Diagnosis: Dutt (in Turner, 1917) described Solierella turneri from India based on a single male specimen. Based on the key of Schmid-Egger et al (2021), it is found that this species shows similarity with some Palearctic species such as S. compedita Costa 1867, S. insidiosa de Beaumont 1964 and S. syriaca de Beaumont 1964 . Female of $S$. turneri is very close to $S$. compedita in its coarse comb-like propodeal sculpture (See figure 1 of Schmid-Egger et al., 2021), maculation on the fore femur, impunctate and shiny episcrobal area and shape of clypeus, but differs by the maculation of fore and mid-tibiae. Male of $S$. turneri is characterized by the last antennal segment longer than previous one, where in S. compedita Costa it is shorter, or as long as to previous one (in S. compedita cretica ssp. last antennal segment is longer than previous one). Female of $S$. turneri is similar to $S$. insidiosa in maculations of fore femur and tibiae, but differ in propodeal sculpture (See figure 5 of Schmid-Egger et al., 2021). Male differ by the length of last antennal segment which is longer than previous one compared to, shorter or at most equal to previous one of $S$. insidiosa. Females of $S$. turneri differ mainly by the maculation of fore femur which is small or at most twice as large as midocellus compared to $S$. syriaca having maculation at least half as long as fore femur. $S$. turneri also differ by mid femur which is black without maculae compared to $S$. syriaca mostly with large maculae, and by maculae of hind tibia which is shorter and does not reaches to the apex compared to $S$. syriaca having maculae as long as hind tibia. Punctations of episcrobal area of mesopleuron is varying even in the specimens collected from the same locality at same time, most of the specimens are provided with shiny and impunctate episcrobal area in varying extent, compared to completely punctated episcrobal area of $S$. syriaca. Male differ by the length of last antennal segment which is longer than previous one compared to S. syriaca having last antennal segment, as long as or shorter than previous one.

Description: Female (hitherto unknown).

Head. Head broader than long; HW1.25-1.30 × HL; IODc 1.20-1.25 × IODv; POD 1.30-1.33 × OOD. Inner eye orbits slightly diverging below; vertex and frons densely punctate, frons with ' $\mathrm{V}$ ' shaped swelling above antennae, bearing a carinae up to basal half of clypeus (Fig. 3). Clypeus punctate, medioapically sparse; anterior margin of clypeus with a medial rounded protuberance (Fig. 4). Antennae slender, scape slightly longer than F1, F1 2.30-2.35 × its apical width. 
Thorax. Scutum and scutellum with fine dense punctures (Fig. 5); episcrobal area of mesopleuron more or less impunctate (Fig. 6). Propodeal dorsum coarse comb-like, propodeal enclosure distinct or inconspicuous, truncate posteriorly, with central fovea at the edge of truncation, posterior sides of propodeum transversely striated with medial longitudinal furrow, without lateral carinae (Figs 5-6 \& 8-9). Forewing as in Fig. 7.

Gaster. Basal portion of G1 slightly concave; base of G2 and G3 slightly constricted; gaster finely punctate, slightly micro coriaceous.

Vestiture. Setae silvery; dense on lower frons and vertex behind eye, sparse on mesopleuron and sides of propodeum; microsetae on antennae, frons, legs, thorax and gaster.

Coloration. Black, mandible ferruginous except basally black; whitish or creamy maculae as follows: transverse band on posterior margin of pronotum interrupted in middle, on pronotal lobe, transverse band on metanotum, mid and hind tibiae and tarsi (often with some black marks on them), few maculae on fore femur and tibia (Figs 1, 2 \& 10).

Body length (up to the apex of G2). 4.50-4.66 mm.
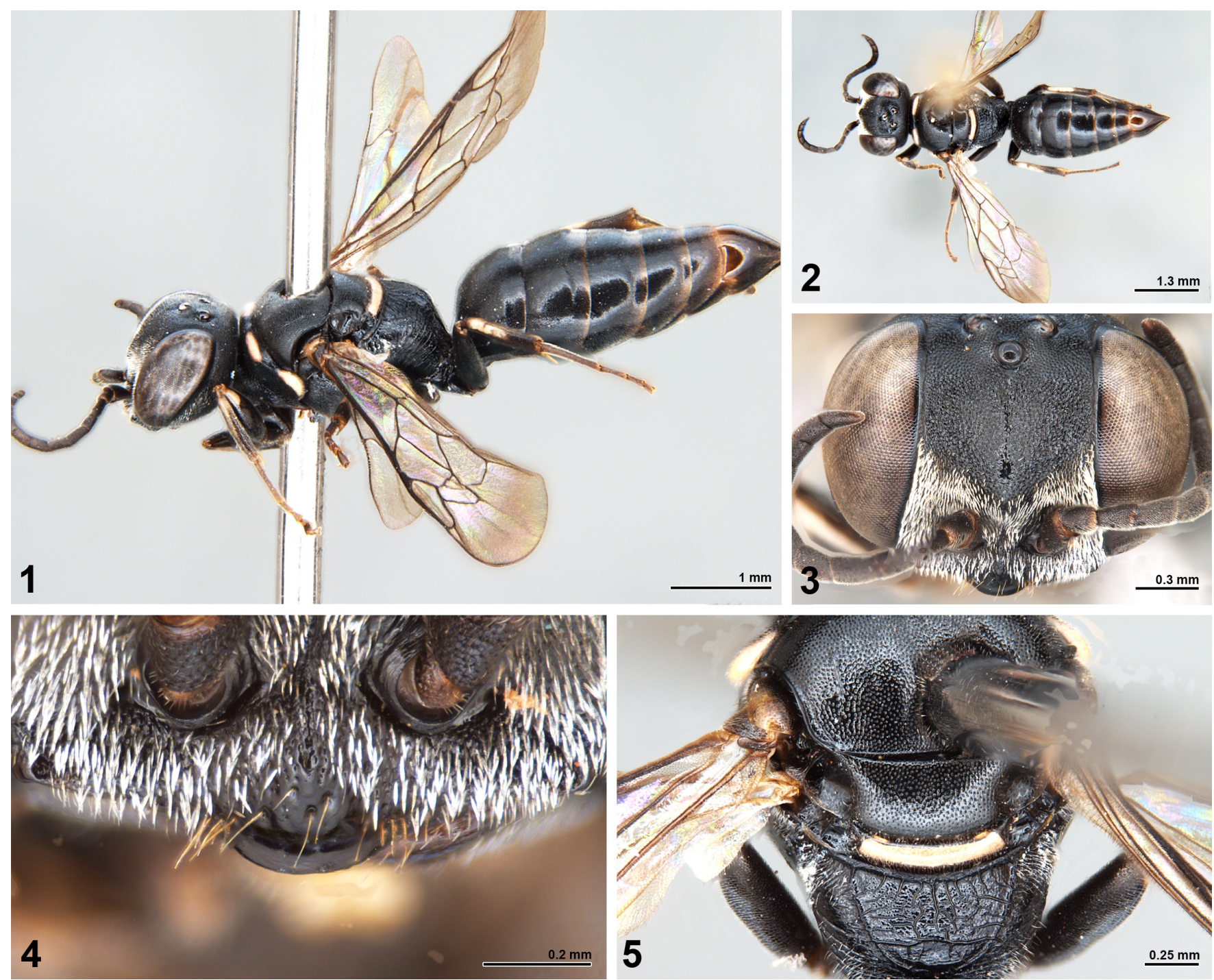

Figures 1-5. Solierella turneri Dutt, female. 1. Habitus, lateral view; 2. Habitus, dorsal view; 3. Head, frontal view; 4 . Clypeus; 5 . Thorax, dorsal view. 

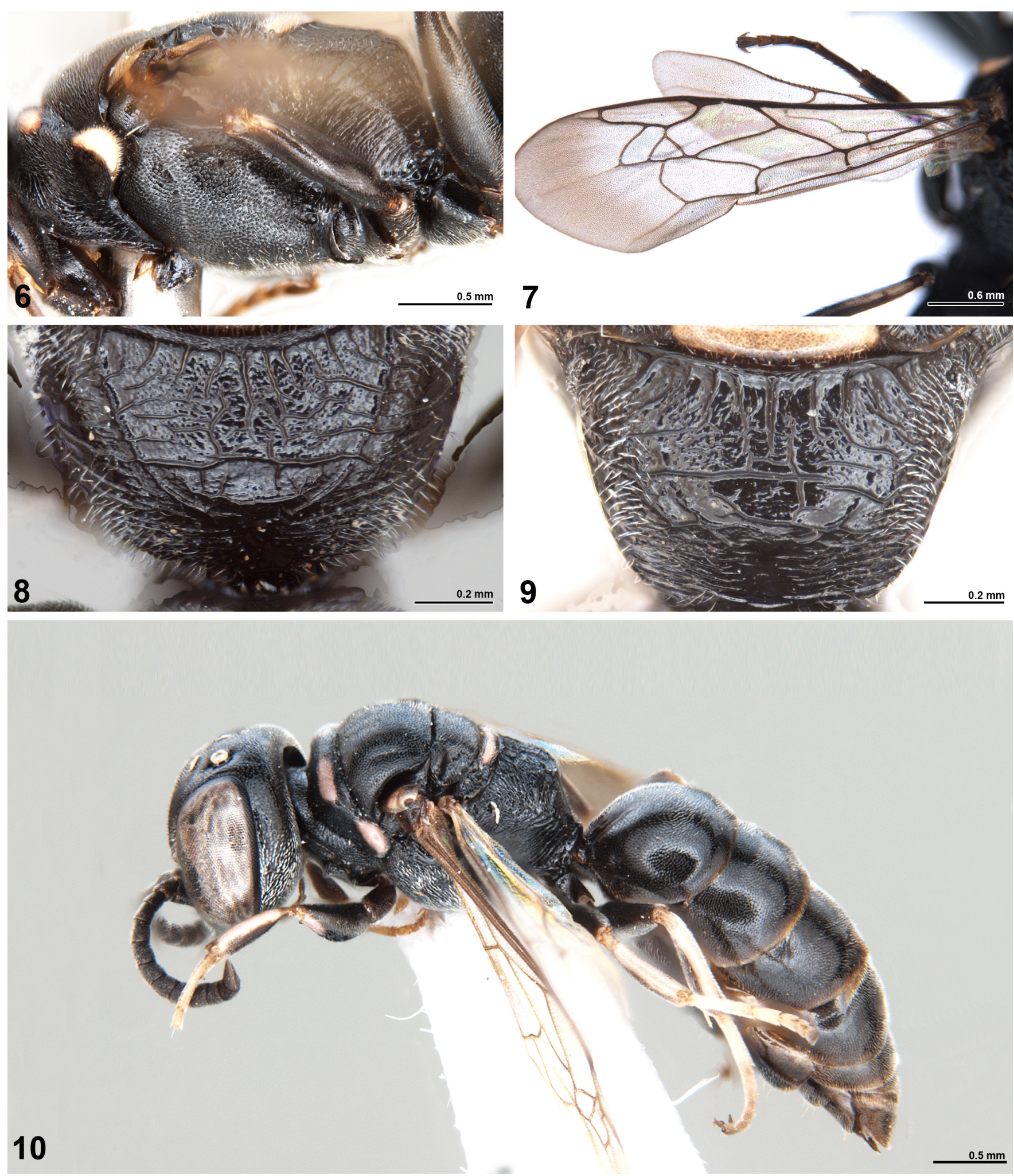

Figures 6-10. Solierella turneri Dutt, female (6-9) and male (10), 6. Thorax, lateral view; 7. Forewing; 8. Propodeum, dorsal view; 9. Propodeum, dorsal view, variation; 10. Habitus, lateral view.

Male. Same as female except clypeus with conspicuous medial carina and medio apically pointed tooth like prominence; propodeal enclosure somewhat ' $\mathrm{V}$ ' shaped (Fig. 15). 
Body length (up to the apex of G2). 3.05-3.08 mm.

Variation. In some specimens, there is a distinct propodeal enclosure present. But in some others, it is inconspicuously present, or with traces of it. Extend of whitish or creamy white maculae on tibiae and tarsi is also vary among specimens, where in some specimens maculae are present on entire tarsi, where in others, it is absent or inconspicuous. Extends of impunctate episcrobal area of mesopleuron vary among specimens.

Distribution. India: Bihar, Karnataka (new record), Kerala (new record), Tamil Nadu (new record).
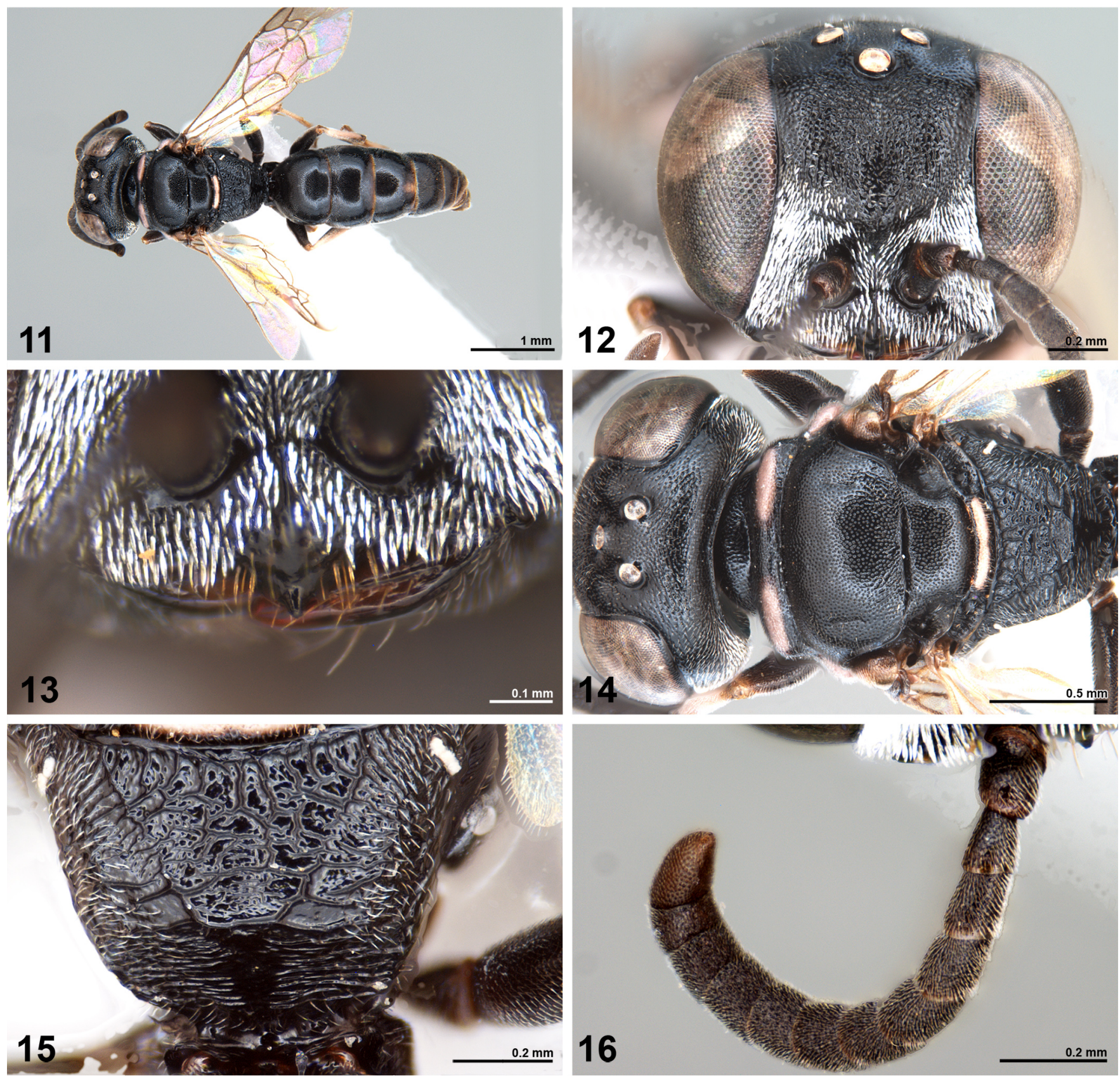

Figures 11-16. Solierella turneri Dutt, male. 11. Habitus, dorsal view; 12. Head, frontal view; 13. Clypeus; 14. Head \& thorax, dorsal view; 15.; Propodeum, dorsal view; 16. Antenna. 

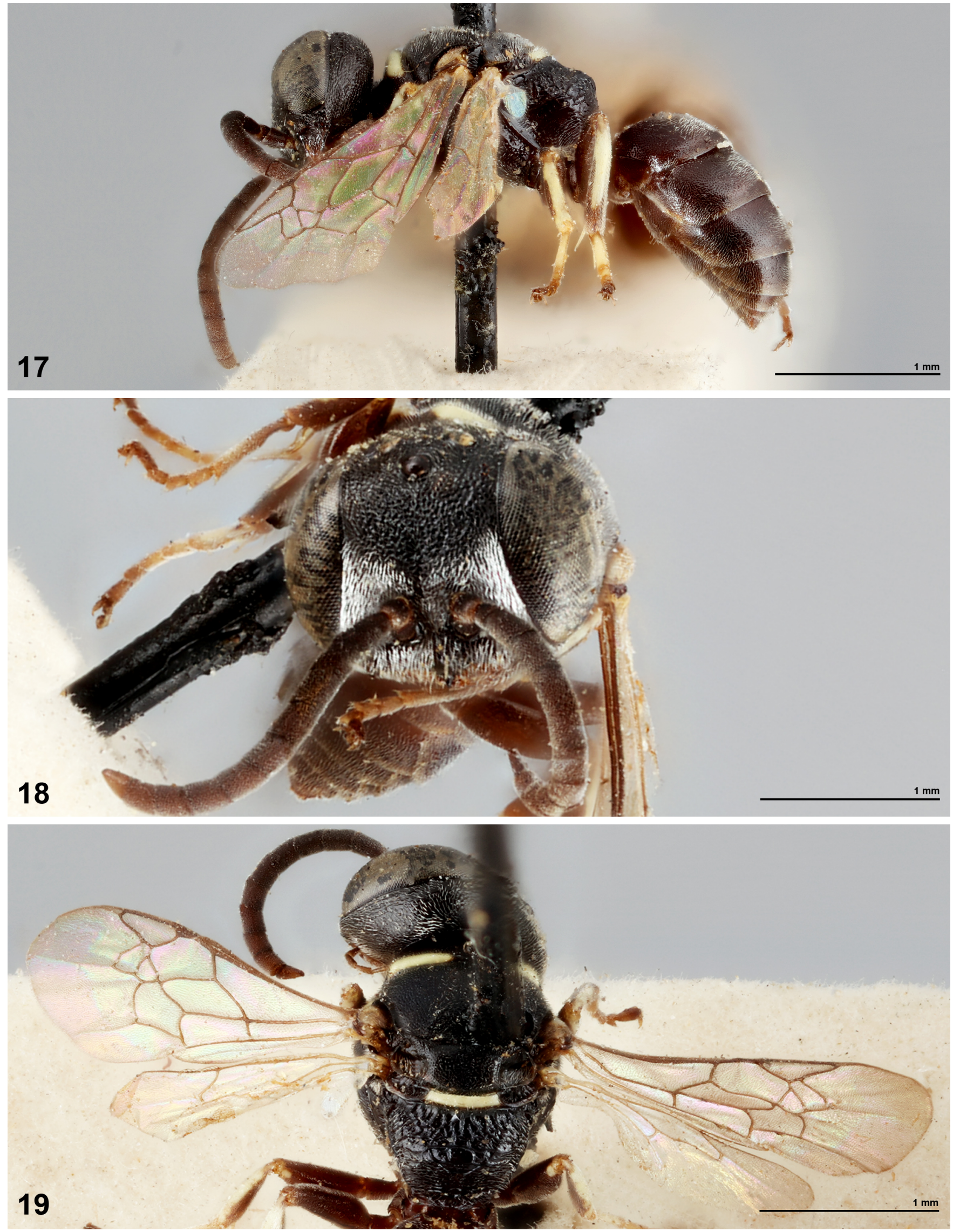

Figures 17-19. Solierella turneri Dutt, male, holotype. 17. Habitus, lateral view; 18. Head, frontal view; 19. Head \& thorax, dorsal view. (C) The Trustees of the Natural History Museum, London. 


\section{DISCUSSION}

Solierella consist of 118 species distributed worldwide, among them Solierella turneri Dutt is the only species which have been reported from India. Hitherto, it is endemic to India, no other studies of Solierella genus have been reported yet from Indian subcontinent. According to Dutt in R. Turner (1917), this species is very close to the Palearctic species S. compedita Costa, but is different in propodeal sculpture. By comparing the propodeal sculpture of the holotype with studied specimens, we have noticed some changes in the intensity of the sculpture. We assume that this may be among variation as seen in S. compedita Costa as mentioned by de Beaumont (1964). From our study, we found that $S$. turneri Dutt is close to Palearctic species such as S. compedita Costa, S. insidiosa de Beaumont and $S$. syriaca de Beaumont in some of the characters as explained in Diagnosis part of paper. Comparing the known fauna of adjacent Palearctic countries, more species can be expected form extensive surveys throughout India.

\section{AUTHOR'S CONTRIBUTION}

The authors confirm contribution in the paper as follows: N.V.A.M. and P.G.K. designed methodology. Both the authors involved in the collections of some specimens and both are involved in the identification also. N.V.A.M. wrote the manuscript with support of P.G.K. Both the authors discussed the results and contributed to the final manuscript.

\section{FUNDING}

University Grant Commission, Govt. of India by means of UGC-SRF.

\section{AVAILABILITY OF DATA AND MATERIAL}

Not applicable.

\section{ETHICS APPROVAL AND CONSENT TO PARTICIPATE}

Not applicable.

\section{CONSENT FOR PUBLICATION}

Not applicable.

\section{CONFLICT OF INTERESTS}

The authors declare that there is no conflict of interest regarding the publication of this paper.

\section{ACKNOWLEDGMENTS}

The authors are grateful to Dr. Dhriti Banerjee, Director, Zoological Survey of India, Kolkata, and Dr. P.M. Sureshan, Officer-in-Charge, Western Ghat Regional Centre, Zoological Survey of India, Kozhikode, and authorities at University of Calicut for providing facilities and encouragements. The authors also acknowledge the valuable help rendered by Dr. Joseph Monks (Curator, Natural History Museum, London) and 'The Trustee of the Natural History Museum, London' for digital loan of type specimen of Solierella turneri Dutt (male) made available under Creative Commons License 4.0. NVAM thankfully acknowledge UGC for financial support by means of UGC-SRF.

\section{REFERENCES}

Bitsch, J., Antropov, A.V., Gayubo, S.F., Leclercq, J., Schmid-Egger, C., Schmid, K., \& Straka, J. (2021) Faune d France 102. Hyménoptères spheciformes d'Europe. Volume 2. Systématique: Deuxième partie. Fédération Française des Sociétes de Sciences Naturelles, Paris. 438 pp

Bohart, R.M. \& Menke, A.S. (1976) Sphecid Wasps of the World. A generic revision. University of California Press, Berkeley, Los Angeles, London. 1 colour plate, IX + 695 pp. 
Carrillo, S.J.L. \& Caltagirone, L.E. (1970) Observations on the biology of Solierella peckhami, S. blaisdelli (Sphecidae) and two species of Chrysididae (Hymenoptera). Annals of the Entomological Society of America, 63, 672-681. https://doi.org/10.1093/aesa/63.3.672

Costa, A. (1867) Prospetto degli Imenotteri Italiani da servire di Prodromo della Imenotterologia Italiana. Tipografia di Antonio Cons, Napoli. 154 pp.

de Beaumont, J. (1964) Insecta Helvetica, Fauna 3, Hymenoptera: Sphecidae. Imprimerie La Concorde, Lausanne. 169 pp.

Krombein, K.V. (1967) Trap-nesting Wasps and Bees: Life Histories, Nests, and Associates. Smithsonian Press, Washington, D.C., 1 unnumbered plate, iii-vi +570 pp.

Kurczewski, F.E. (1967) A note on the nesting behavior of Solierella inermis (Hymenoptera: Sphecidae, Larrinae). Journal of the Kansas Entomological Society, 40, 203-208.

Newton, R.C. (1960) The nesting habits of the wasp, Solierella sp., and the location of its egg on the grasshopper, Ageneotettix deorum. Journal of Economic Entomology, 53, 958-959. https://doi.org/10.1093/jee/53.5.958

Pulawski, W.J. (2021) Catalog of Sphecidae. Available from: https://www.calacademy.org/scientists/projects / catalog-of-sphecidae [Accessed 15th June 2021].

Schmid-Egger, C., Fallahzadeh, M. \& Sadeghi, M. (2021) A review of Solierella Spinola, 1851 (Hymenoptera, Crabronidae) from Iran with description of four new species. Zootaxa, 4920 (1), 101-113. https://doi.org/10.11646/zootaxa.4920.1.4

Turner, R. (1917) On a collection of Sphecoidea sent by the Agricultural Research Institute, Pusa, Bihar. Entomological Series, 5, 173-205.

Williams, F.X. (1927) Notes on the habits of the bees and wasps of the Hawaiian Islands. Proceedings of the Hawaiian Entomological Society, 6, 425-464.

Williams, F.X. (1950) The wasps of the genus Solierella in California (Hymenoptera, Sphecidae, Larrinae). Proceedings of the California Academy of Sciences, (Series 4), 26, 355-417. https:/ / doi.org/10.1086/398493 
كونه Hymenoptera: Crabronidae: Crabroninae) Solierella turneri Dutt, 1917 از هند: توصيف ماده و كزارش هاى جديد يراكنش

آيشا مواداثو يوتووايى كيريش كومار

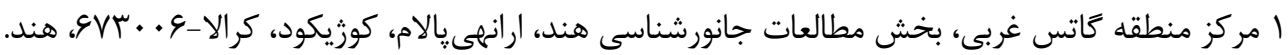

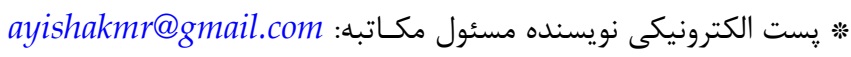

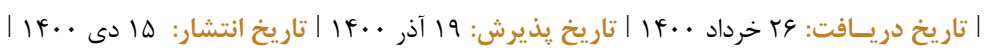

(Hymenoptera: Crabronidae) Solierella turneri Dutt, جكيـده: زنبور 1917

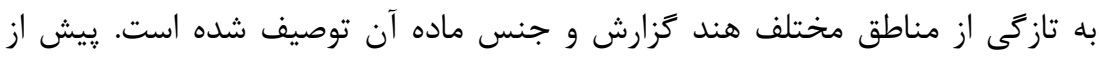

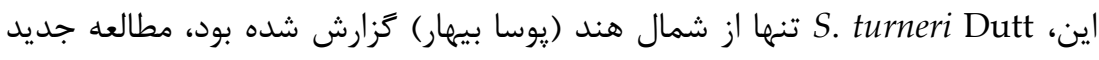

نشاندهنده يراكنش اين كونه تا جنوب (كرالا، تاميل نادو و كارناتاكا) است.

وازَّـان كليدى: زنبورهاى حفار، Apoidea Miscophini، كزارش جديد، جنوب

هند 